Transportation Research Forum

Book Review: Shifting Out of Park: Moving Auto Safety from Recalls to Reason

Book Author(s): Kevin M. McDonald

Review Author(s): George E. Hoffer

Source: Journal of the Transportation Research Forum, Vol. 46, No. 3 (Fall 2007), pp. 109-111

Published by: Transportation Research Forum

Stable URL: http://www.trforum.org/journal

The Transportation Research Forum, founded in 1958, is an independent, nonprofit organization of transportation professionals who conduct, use, and benefit from research. Its purpose is to provide an impartial meeting ground for carriers, shippers, government officials, consultants, university researchers, suppliers, and others seeking exchange of information and ideas related to both passenger and freight transportation. More information on the Transportation Research Forum can be found on the Web at www.trforum.org. 
McDonald, Kevin M. Shifting Out of Park: Moving Auto Safety from Recalls to Reason. Tuczon, AZ: Lawyers \& Judges Publishing Co., Inc., 2006. ISBN 1933264-16-0

\title{
Shifting Out of Park
}

\author{
by George E. Hoffer
}

\section{INTRODUCTION}

This book will be of interest to students and researchers of federal regulation and regulatory history, as well as practitioners in the automotive recall arena. Kevin M. McDonald, assistant general counsel for Volkswagen of America, has written a thoroughly researched, though narrowly focused primer, on the automotive recall in the United States and, for comparative reasons, in several other countries. The book, written in text-like but opinionated prose, traces from inception the history and enforcement of the automotive recall. The overriding theme of the book, with which I am sympathetic, is the lack of reasonableness in interpreting and enforcing the Act and the misguided emphasis on the vehicle as the primary focus of highway safety regulation. My primary criticisms of this work are the conspicuous omission of references to the significant body of peer-reviewed research on the economic aspects of the motor vehicle recall and the failure, at times, to see an issue from NHTSA's perspective.

\section{CENTRAL THEMES OF THE TEXT}

The book begins with a brief forward by Dr. Leonard Evans, recently retired from General Motors, who for decades has been the most prominent corporate-affiliated research scientist on automotive safety. In the author's Preface, McDonald acknowledges Evans for his critical review of the manuscript.

Evans distinctly lays out the themes of McDonald's book in his forward. They are:

(1) Traffic safety has three components-driver safety, roadway safety, and vehicle safety.

(2) While the latter is by far the least important of the three, NHTSA devotes disproportionate attention to it.

(3) The public face of governmental (NHTSA) regulation of vehicle safety has been the automotive recall.

(4) Yet automotive recall enforcement has had virtually no impact on the 40,000-plus annual automotive fatalities in the United States.

(5) Indeed, given millions of observations, there is no evidence that vehicles recalled and then repaired under NHTSA recall campaigns have lower risks than those not returned by their owners (clearly, the Firestone recall being an exception-see discussion below).

(6) Consequently, Americans would be far better served if more resources were devoted to driver and highway safety.

\section{WHAT IS FOUND HERE}

The book consists of eight chapters. Some of the material in the book draws on research that the author published previously in peer-reviewed law journals. 


\section{Public Transport in Developing Countries}

Chapter 1 is an introduction-overview. The high point of the chapter is the chronicling of why the recall process needs serious reform. The reasons include:

- Automotive manufacturers have been browbeaten by the special interests, read: trial lawyers, self appointed consumer interest groups, bureaucrats.

- $\quad$ NHTSA has failed to protect its turf and resist calls from the above special interest groups for trivial recalls.

- The NHTSA recall letter is outdated.

- Owners of recalled vehicles are not held responsible for failure to respond.

- The automotive recall process must be amended to incorporate reason.

Chapter 2 reviews automotive accidents and their origins. Factors discussed include:

- The global nature of the motor vehicle accident-more than 1.2 million people die a year worldwide

- The cost in life, limb and property in the UNITED STATES-about 2.3\% of the GDP.

- NHTSA's ill-advised focus on the vehicle instead of the driver during the 1970s and 1980s. To paraphrase the 1992 Clinton campaign slogan, it's the driver stupid -the drunk, the cell phone user, and the teen.

- Emerging technologies-whether they are cell phones, games, or navigational distraction-pose increasing safety risks, not the motor vehicle defect.

Chapter 3 reviews why and how safety legislation was enacted in the UNITED STATES and the initial amendments thereto. Events of note include:

- The Ralph Nader-GM Chevy Corvair conflict.

- The recall match "made in heaven" between Nader and Senator Patrick Moynihan (D-NY).

- The early relatively benign years of regulation, termed the years of "Gentlemen's Agreements."

- The 1974 amendments to the Act which ushered in the present more stringent (some, including this reviewer would call dictatorial, no common sense) enforcement regime.

Chapter 4 chronicles the landmark recalls.

- Recall battles recounted range from the GM "X" car locking brakes to the Chrysler "Cloud" car rear seatbelt anchors.

- McDonald concludes that even when manufacturers win in court, they lose in the court of public opinion.

- But the recall system is so stacked against auto manufacturers, they perceive no choice but to cave in.

Chapter 5 puts a microscope to the grandfather of all recalls to date: the Firestone tire recall. It chronicles the impact on Firestone and Ford (this reviewer served as a Ford consultant in a number of the civil litigations in state and federal court which followed). Highlights of the chapter include:

- A background review, including the ignored early warnings.

- Ford management's reaction.

- Congress" "lightning" response by enacting the "THREAD Act" in October, 2000.

- An analysis of the THREAD Act's impact on a variety of parties including foreign governments and NHTSA.

Chapter 6 continues to analyze the consequences of the Firestone tire recall and the resulting THREAD Act.

- McDonald identifies three losers: Firestone, Ford, and NHTSA.

- Into the breach step the plaintiffs bar, activist consumer groups, and technocrats in proactive states. 
- These groups have attempted to usurp NHTSA's sole authority over the recall process.

- McDonald concludes bedlam would result unless the recall remains the exclusive domain of NHTSA.

Chapter 7 reviews other automotive and non-automotive recall regimes.

- Recall processes of other Federal agencies such as the EPA, FDA, and USDA are reviewed.

- The processes are compared in a highly useful matrix.

- The automotive recall regime is analyzed in three other motorized countries: Austria, Germany, and Canada.

- McDonald concludes that all three countries have superior regimes to that of the United States.

Chapter 8 concludes the book with McDonald's recommendations:

- To NHTSA: rethink the recall-many border on the absurd.

- To NHTSA: penalize automotive owners for not responding to recall notices (a decade ago I co-authored a peer-reviewed article on this subject).

- To the automotive manufacturer: fight each recall if you believe that you are in the right.

\section{CONCLUSION}

I believe that this is a well written and biting work on the history of the automotive recall and the recall process in the United States from the perspective of someone who has been in the trenches. I empathize with his frustrations. My main criticisms are that he has virtually ignored the rich body of literature that has developed in the peer-reviewed business and economics literature on the automotive recall over the last 30 years and that he has failed to put himself, at times. in NHTSA's shoes.

George E. Hoffer is a professor at the School of Business, Virginia Commonwealth University in Richmond, Virginia. He has authored or coauthored over 75 academic articles primarily on automotive industry topics. His research has been published in academic journals such as American Economic Review, Journal of Political Economy, and Journal of Business. He holds a Ph.D. from the University of Virginia. 